\title{
Stress Management Interventions in Polish Companies - Research Results
}

\author{
Dorota Molek-Winiarska \\ Human Resources Management Department, \\ Wroclaw University of Economics, Poland
}

\begin{abstract}
Numerous studies on work-related stress and stress management interventions have led to the formulation of some rules and theories. Nevertheless, the methodology of this kind is still imperfect. There is a tremendous need to do comparative research on different kinds of interventions. This article attempts to answer the following questions: Are entrepreneurs familiar with the idea of the stress management interventions? Have their implementations been introduced after taking into consideration the causes, costs and results of stress? Are the interventions effective or not? The results show that $45 \%$ of the employers know the idea of stress management interventions (SMI) and about $17 \%$ implement them. The most popular intervention is training supervisors in stress management and training employees to cope with stress. The results show also a relatively low quality of interventions of SMIs.
\end{abstract}

Keywords: occupational stress, work-related stress, interventions, stress management, costs.

\section{Introduction}

Stress management involves interventions connected with stress reduction in every organization. It is difficult to find a concise definition of this term due to the difficulties with applying these interventions rather than their innovative characteristic. Researchers dealing with this topic are not interested in its theoretical or praxeological aspect. They focus on presenting their research methodologically correct so that they could reflect the existing organisational reality. It encourages other researchers and people experienced in management to introduce the new plans in various sectors and organizations.

This article aims at presenting the research on the stress management interventions in Polish enterprises, answering the following questions: 
Are Polish entrepreneurs familiar with the idea of the stress management interventions? Do they use them? Have their implementations been introduced after taking into consideration the causes, costs and effects of stress?

The background of the presented results in the research is a brief outline of the current state of knowledge about stress, its reduction programs and costs, which are, due to the lack of prevention, inevitable. The state of knowledge and research regarding the sources of stress in an organization, and psychological effects of chronic stress were omitted mainly due to the length of the article. These topics are dealt with in other works of the author.

\section{The nature of stress}

While studying the literature on stress, many various definitions of this term may be found. Nonetheless, the opposing views on this topic are rather complementary than competitive, as the issue of stress itself is immensely complex and varied. Searching for its definition three main groups of concepts must be mentioned, each of which highlights different aspect of stress.

The first group of definitions describes stress as a stimulus causing a specific set of reactions (emotional, physiological). This is early research on stress conducted among others on parachute jumpers ${ }^{1}$. Such an attitude implies that basically a certain set of factors affecting all people causing stress reactions (such as a parachute jump or a death of a close relative) exists. Nevertheless, there are many situations in which one will suffer from stress and another will not. Moreover, even the same person can react differently in terms of stress in the same situation. These conclusions point out the need for adding the next element to fully define the phenomenon of stress.

The second group of the definitions applies to perceiving stress as a reaction to an external situation. The precursor of such an approach was Hans Selye who defines stress as a nonspecific body reaction to everything we require from it $^{2}$. Selye's concept was based on the Walter Cannon's theory of homeostasis. He claimed that a living organism aims at maintaining their internal balance despite all the external factors. If these factors destroy their balance, the organism launches many processes which are to restore the initial state. This

1 I. Janis, Psychological stress. Psychoanalytic and Behavioral Studies of Surgical Patients, Wiley\&Sons, New York 1958, p. 7; J, Reykowski, Funkcjonowanie osobowości w warunkach stresu psychologicznego, PWN, Warszawa 1966, p. 189.

2 H. Selye, Stres okietznany, PIW, Warszawa 1977, p. 25. 
drive is a nonspecific reaction as it is not directly connected to the cause of the imbalance, whether it was due to bad weather, drugs, strong emotions or pain is of no importance. In his attitude to stress Selye mainly depends on the physiological reactions' analysis ${ }^{3}$, regardless of cognitive assessment as a factor causing stress.

The third group of definitions puts stress into psychological frames. It is described as a mental state consequential at the interaction between a human being and its environment. The most popular definition is the one by Richard Lazarus, who defines psychological stress as "a particular transaction between a person and their environment which is by the person evaluated as tiresome and using up their resources and threatening their welfare" ${ }^{\prime \prime}$. When faced with a stressor, a person evaluates the potential threat. This is called primary appraisal. It is an individual's judgment about the significance of an event as stressful, challenging, controllable, positive or irrelevant. Facing a stressor, the second appraisal follows, which is an assessment of people's coping resources ${ }^{5}$.

In this view, stress is an absolutely subjective phenomenon and can happen only if an individual assesses the situation as stressful. It allows to explain the interpersonal and intrapersonal differences in feeling stress.

Regardless of the three aforementioned definitions complementing each other, it should be pointed out that there are two more features of the phenomena. First of all, stress is not something we should always avoid. Quoting H. Selye: "A total freedom from stress means death"6, which means that eliminating stress from the individual's life is impossible. There is another crucial characteristic connected with this fact because stress can be either positive - eustress or negative - distress. Although both of them launch the same physiological reactions, they have diametrically opposed emotional, cognitive and behavioral effects. Distress is related to negative emotions (fear, anxiety, anger, frustration); whereas the symptoms of eustress are happiness,

3 There are mentioned physiological reactions such as: increased frequency of myocardial contraction, constriction of blood vessels inside the body and extending to the periphery, increased heart rate and blood, pressure changes in brain waves from synchronized $\alpha$ waves to $\beta$ waves of high frequency and low amplitude, decrease alimentary muscles tension, cessation of secretion of digestive glands and digestive function, increase in the secretion of adrenaline, increased electrostatic conductivity, changes in skin temperature, muscle tension, increased sweating, and mydriasis (Selye, Stres..., op. cit. PIW, Warszawa 1977, pp. 38-42, J. Terelak, Stres psychologiczny, Branta, Bydgoszcz 1995, p. 16).

4 R. Lazarus, S. Folkman, Stress, Appraisal and Coping, Springer, New York 1984, p. 19.

5 R. Lazarus, Psychological Stress and the Coping Process, McGraw-Hill Book Company, USA 1966, p. 25.

6 H. Selye, Stres..., op. cit., PIW, Warszawa 1977, p. 30. 
impatience, excitement. It is the positive force which is a motivating factor, enhances the subjective quality of life, brings happiness, contentment and a feeling of wish - fulfillment.

Occupational Stress (Work-Related Stress) in the literature, both Polish and foreign, is defined as a negative phenomenon. Typically, the researchers of occupational stress form its definition based on the concepts of psychological stress. Making a comprehensive presentation of various concepts of organizational stress one can indicate that it is a psychological state resulting from the continuous interaction between the demands of the environment and the individual resources of the employee. An individual feels the stress when the demands of the job outweigh the resources to deal with them ${ }^{7}$. In other words, stress is the result of a partial or complete loss of control over actions taken by the employee in the organization ${ }^{8}$. An important issue is the fact that the situation itself is not stressful, because stress is the reaction of the individual the impact of the environment. This means that the situation is causing stress symptoms for some people, but not for others. C. Cooper on the basis of studies in the Institute for Social Research at the University of Michigan, defines this relationship as a theory of compatibility. He means firstly "matching the skills and human ability to the demands placed on their profession," and, secondly, the ability to meet the needs of the individual by the work environment ${ }^{9}$. This adjustment is connected to the relation between the situation and an individual with their specific personality, behavior, way of thinking and experiencing.

Regardless of the various concepts that describe organizational stress as a relationship between workers and their environment, the study of this phenomenon cannot neglect two other views. Thus, while analyzing the environment in search for causes of stress and examining its short-and long-term effects it is inevitable to refer to the concept of stimuli or Selye's theory.

7 C. Cooper, R. Payne, Stres w pracy, PWN, Warszawa 1987, p. 122; C. Cooper, P. Liukkonen, S. Cartwright, Stress Prevention in the Workplace, European Foundation for Improvement of Living and Working Conditions, Dublin,1996, p. 28; T. Cox, A. Griffiths, E. Rial González, Research on Work-Related Stress, Report for EU OSHA, Nottingham 2000, p. 87; N. Ogińska-Bulik, Stres zawodowy w zawodach ustug społecznych, Difin, Warszawa 2006, p. 16; I. Houtman Work-related stress, Report for European Foundation for the Improvement of Living and Working Conditions, Dublin 2007.

8 M. J. Schabracq, J. A. Winnubst, C. Cooper, Work \& Health Psychology, John Wiley\&Sons, West Sussex 2003, p. 27.

9 C. Cooper, R. Payne, Stres..., op. cit., p. 123. 


\section{Stress management}

Stress management is a set of organized interventions aspiring to eliminate or reduce occupational stress. They are also aimed at helping individuals and develop the methods of coping with stress ${ }^{10}$. Depending on the size of a company, type of business, budget for the interventions and many other more specific factors many various stress management interventions can be described. A vast majority of researchers divide the stress management interventions according to a criterion of range of influence ${ }^{11}$. Such interventions are divided into Organizational Level Interventions (OLI) and Individual Level Interventions (ILI).

There is a division of interventions into three categories according to their aims:

- Primary interventions - diagnosis and elimination or reduction of causes of stress

- Secondary interventions - supporting employees' ability to cope with the existing stress by development of techniques and skills

- Tertiary interventions - psychological or medical help in coping with the psychological and somatic results of stress ${ }^{12}$.

The first group of programs applies to the organizational level interventions, the second and third are the interventions focused on improving individual's functioning.

According to the research organizational level interventions are implemented less often than individual ones. The reason for this is usually work and time - consuming process of preparation, organization and implementation

10 D. Molek-Winiarska, Organizacyjne $i$ indywidualne programy zarzadzania stresem, „Współczesne Zarządzanie” 2010, No. 1, p. 118.

11 C. Cooper, P. Liukkonen, S. Cartwright., Stress Prevention..., op. cit., p. 24; T. Cox, A. Griffiths, E. Rial González, Research on..., op. cit., p. 112; J. J. L. van der Klink, R. W. B. Blonk, A. H. Schene, F. J. H. van Dijk, The Benefits of Interventions for Work-Related Stress, "American Journal of Public Health" 2001, Vol. 91, No. 2, p. 270; P. Dewe, M. O’Driscoll, Stress Management Interventions: What Do Managers Actually Do? "Personel Review" 2002, Vol. 31, No. 1/2, p. 144; K. M. Richardson, H. R. Rothstein, Effect Of Occupational Stress Management Intervention Programs. A Meta-Analysis, "Journal of Occupational Health Psychology" 2008, Vol. 13, No. 1, p. 69; R. A. Graveling, J. O. Crawford, H. Cowie, C. Amati, S. Vohra, A Review of Workplace Interventions that Promote Mental Wellbeing in the Workplace, Draft Report, Institute of Occupational Medicine, Edinburgh 2008, p. 15.

12 T. Cox, A. Griffiths, E. Rial González, Research on..., op. cit., p. 111; A. S. Dalgren, G. E. Gard Soft Values With Hard Impact - A Review Of Stress Reducing Interventions On Group And Organizational Level, "Physical Therapy Reviews" 2009, Vol. 14, No. 6, p. 370. 
of such a program, thus, its higher cost ${ }^{13}$. Nonetheless, their effects in terms of reduction of organizational stress are much bigger and long - term than individual interventions. Their effectiveness is connected with not only eliminating (or reduction) of the cause of stress, but also are better prepared and their effects are well monitored and compared to measurable indicators set at the beginning of implementation ${ }^{14}$. The reason why it is worth implementing the organizational interventions is not only a well - known saying that prevention is better than cure, but also a bigger long - term benefits. If working conditions are linked to high pressure and high level of stress even the strongest and best - prepared employees will suffer from it at last. This will be connected to recovery costs or other financial effects of stress which are mentioned in this article later on.

Among many elaborations on stress reduction interventions on organizational level the following are to be mentioned:

- monitoring and control of workstations' ergonomics,

- making changes in work organization (e.g. flexible working hours, job rotation),

- defining professional roles for their clarity and to avoid conflict, overworking or role ambiguity,

- increasing the sense of subjectivity through participative management and effective communication systems,

- providing training to managers in the field of stress management,

- reduction of work-family conflict ${ }^{15}$.

Individual level interventions are undoubtedly a predominant group of interventions in terms of stress reduction in companies. It happens thanks to their advantages listed by L. Murphy. It is possible to implement them quickly and assess their effectiveness. They are also flexible and can be adjusted to various needs of employees, who are able to use them at work and in their private lives ${ }^{16}$. I. Houtman points out other reasons for their more common implementation:

- managers often have the opinion that problems with stress are due to difficulties with coping with it and an individual resistance to it,

13 T. Cox, A. Griffiths, E. Rial-González, Research on..., op. cit. p.114; A. S. Dalgren, G. E. Gard, Soft values..., op. cit. p. 369.

14 I. Houtman, Work-related..., op. cit. p. 28.

15 R. A. Graveling et al, A Review..., op. cit. p. 15; A. S. Dalgren, G. E. Gard Soft values..., op. cit. p. 370; D. Molek-Winiarska, Organizacyjne... op. cit. p. 119.

16 T. Cox, A. Griffiths, E. Rial González, Research on..., op. cit., pp. 114-119; A. S. Dalgren, G. E. Gard, Soft values..., op. cit., p.118. 
- in the managers interest it is not to thoroughly change the organization of company's work just to reduce stress,

- it is much easier to implement an intervention programme at the individual level while maintaining an adequate standard of quality and methodology of implementation than while dealing with the project at the organizational level ${ }^{17}$.

However, it seems that one of the most important reasons for favoring far more common implementations of stress reduction programs at the individual level is much lower costs of implementation and monitoring. The individual level interventions list the following activities:

- training in coping with stress skills,

- training to improve soft skills (communication, time management, self-motivation, etc.),

- psychological counseling, therapeutic meetings, external coaching,

- promotion of physical activity (exercise, dance, massage),

- health promotion for healthy lifestyle,

- training in relaxation, meditation etc ${ }^{18}$.

\section{Cost of occupational stress}

The issue of the financial cost of stress is relatively not so often discussed. But if such data is quoted, there are great differences between the data reported by various authors. To analyze the costs incurred as a result of the occupational stress and the employees performance should be divided into the costs directly incurred by an employee and the costs incurred by an organization. The former include expenses related to treatment of diseases caused by chronic stress ${ }^{19}$, medical expenses due to accidents at work (regardless of the damages) and costs associated with the loss of current and future income as a result of damage to

17 I. Houtman, Work-related..., op. cit., p. 25.

18 B. Gardner, J. Rose, O. Mason, P. Tyler, D. Cushway., Cognitive Therapy And Behavioural Coping In The Management Of Work-Related Stress: An Intervention Study, "Work \& Stress" 2005, Vol. 19, No. 2, p. 139; T. Cox, A. Griffiths, E. Rial González, Research on..., op. cit. p. 118; R. A. Graveling et al., A Review..., op. cit., pp. 33-85; D. Molek-Winiarska, Organizacyjne..., op. cit., p. 122.

19 Studies show that such diseases include coronary heart disease and cardiovascular disorders and diseases associated with the digestive system - stomach ulcers, duodenum, intestines (J. Terelak, Stres..., op. cit., p. 209). 
health. There are also emotional costs, which, though difficult to measure, are the dominant effects of prolonged stress ${ }^{20}$.

The costs incurred by the organization:

- loss of productivity costs,

- cost of compensation for workers,

- costs of substitutions in case of absence,

- staff turnover, costs associated with recruiting and employee selection and adaptation to a new job,

- cost of accidents at work (the destruction of materials, equipment),

- costs resulting from theft, sabotage and other counterproductive behaviour, as a result of "compensation" for stress,

- cost of medical services (in some organizations or countries).

Additional effects of the lack of action in reducing the effects of psychosocial stress are such as: a decrease in morale among employees, a deteriorating image of the company, a decline in attractiveness of the company, negative atmosphere at work.

There is much and not always concurrent information on the costs of occupational stress. T. Cox and others quoting a European Agency for Safety and Health at Work report emphasize the estimates of total costs borne by workers, the economy and society due to accidents at work and work-related diseases.

The results showed that the costs incurred by employers in respect of accidents at work and work-related diseases in Britain in 1990 amounted to from 4.5 to 9 billion pounds. The costs incurred by victims and their families amounted to about 4.5 billion pounds ${ }^{21}$. The data collected a decade later regarding the cost of absenteeism whose stress is the second most common cause indicates the loss of 10 billion pounds a year ${ }^{22}$. In 2002, the European Commission announced that the annual costs associated with the pathological

20 Many research show that the psychological effects of chronic stress are anxious neurosis, obsessive-compulsive disorders, addiction and burnout syndrome (C. Cooper, R. Payne, Stres..., op. cit. pp. 44-62; J. Terelak, Stres..., op. cit., p. 208; D. Molek-Winiarska, Skutki stresu zawodowego, in: Dysfunkcje i patologie w sferze zarzqdzania zasobami ludzkimi, Ed. Z. Janowska, Wydawnictwo Uniwersytetu Łódzkiego, Łódź 2011, p. 314; M., Milczarek, E. Schneider, E. Rial González, OSH In Figures: Stress At Work - Facts And Figures, Report for EU OSHA, Luxemburg 2009, pp. 21,111.).

21 T. Cox, A. Griffiths, E. Rial González, Research on..., op. cit., pp. 114-119; A. S. Dalgren, G. E. Gard, Soft values..., op. cit., p. 28.

22 S. I. Giga, A. Noblet, B. Faragher, C. Cooper, The UK Perspective: A review of Research on Organisational Stress Management Interventions, "Australian Psychologist" 2003, Vol. 38, No. 2, p. 158. 
effects of occupational stress in the fifteen EU countries amounted to $€ 20$ billion. The same studies show that $50-60 \%$ of cases of absence from work is associated with stress and its consequences ${ }^{23}$. Earlier studies, published in the report of the European Foundation for Working Conditions in the European Union in 1996, indicate that there are around 600 million working days lost across the European Union ${ }^{24}$. Dutch studies provide very precise data on the costs of stress in terms of an employee ${ }^{25}$. The authors suggest that the costs of stress per employee are $€ 1,368^{26}$.

In contrast to the data provided it is worth noting to the costs of preventing stress and its effects. These costs can be divided into those which are focused on the employee and the organization. The former concern the methods of diagnosis of stress and its effect on employees. Therefore they include:

- measuring the level of subjectively experienced stress, the study of personality traits and temperament relevant to the resistance to stress, studies of individual methods of coping with stress,

- training in methods of coping with stress,

- training in methods of stress reduction (relaxation, physical exercise) and modification of behavior in stressful situations.

Organizational costs apply to the investment in improving the physical working conditions, creating ergonomic work stations, establishing, maintaining and supervising the prevention of stress at work and also promotion of the intervention and training time (at work).

The cornerstone of the entrepreneurs' interest in stress prevention is comparing the costs of stress effects to the costs of implementing and monitoring programmes of its reduction. Wayne Cascio shows that "it is a lot cheaper to take care of an employee's health ${ }^{27}$ than cover the costs of their illness, rehabilitation and replacement at work" 28 . The author shows that $80 \%$ of U.S. companies employing at least 50 employees, uses a variety of health promotion. The cost of such interventions varies depending on the company size, the degree of necessary changes and the selection of the implementing institution. According to the data based on the experience of American

23 M. Milczarek et.al, OSH in figures..., op. cit., p. 9.

24 T. Cox, A. Griffiths, E. Rial-González, Research on..., op. cit., p. 29.

25 in: M. Milczarek, E. Schneider, E. Rial González, OSH in figures..., op. cit., p. 113.

26 Including the cost of absenteeism - $€ 527$, the cost of inability to work $-€ 609$, the costs of returning to work after a long absence $-€ 103$, the cost of medical care and treatment $-€ 129$.

27 Health is defined here as the psychological, social, emotional, spiritual and intellectual balance, which means that it also includes a range of stress-related reactions (W. F. Cascio, Kalkulacja kosztów zasobów ludzkich, Oficyna Ekonomiczna, Kraków 2001, p. 135).

28 W. F. Cascio, Kalkulacja..., op. cit., p. 135. 
companies, the cost of an intervention of health promotion at work each year is between $\$ 70$ and $\$ 130$ per employee ${ }^{29}$. Cost analysis of prevention of stress and its effects in the Netherlands conducted in 2001 indicated a similar trend. As mentioned earlier, stress costs per employee amounts to $€ 1,368$. Meanwhile, the cost of prevention programmes is $€ 400$ per employee per year ${ }^{30}$. T. Cox points to analyses of the effects of stress reduction programmes. According to studies cited by him, $\$ 1$ spent on stress management intervention on an individual brings to $\$ 5.5$ profit for the organization following an increase in labor productivity and reduction of the symptoms of stress ${ }^{31}$.

In view of this data it seems to be economically justified to take preventive action to reduce organizational stress. It is therefore very interesting for the researcher to explore and delve into this issue in Polish reality. Later in this article there is a study on the level and type of implementations used in Polish enterprises.

\section{The implementation of stress management interventions in polish companies}

According to literature, one can find many studies related to the implementation of stress management interventions ${ }^{32}$. Some of them are methodologically correct and concern mainly secondary or tertiary interventions. The author of this article conducted a research on Polish companies. The main aim of this study was to investigate the level of awareness and implementation of different kinds of interventions and also the level of methodological correctness of those actions. The author is aware that the assessment of the intervention was done in an indirect way, by asking HR specialists about the process of implementation, not by assessing the intervention itself.

This study was conducted in Polish organizations between 2009 and 2011. About 700 surveys were sent to human resources managers in large and medium-sized companies or the owners of small-sized organizations. The

29 Ibidem. p. 139.

30 in: M. Milczarek et al., OSH in figures..., op. cit., p. 113.

31 T. Cox, A. Griffiths, E. Rial González, Research on..., op. cit., p.111.

32 R. A. Graveling et al., A Review..., op. cit.; P. Dewe, M. O’Driscoll, Stress Management..., op. cit.; K. Nielsen, R. Randall, A. Holten, E. Rial González, Conducting Organizational-Level Occupational Health Interventions: What Works? "Work \& Stress" 2010, Vol. 24, No. 3; S. Leka, A. Jain, G. Zwetsloot, T. Cox, Policy-Level Interventions and Work-Related Psychosocial Risk Management in the European Union, "Work \& Stress" 2010, Vol. 24, No. 3. 
return was 200 surveys. Follow-up studies based on implementing the stress management interventions in several companies are being done by the author.

More than a half of companies in the sample represent large organizations, which hire more than 250 employees. $28 \%$ are the medium-sized companies and $13 \%$ are small-sized organizations.

Figure 1. The level of employment in the companies sample

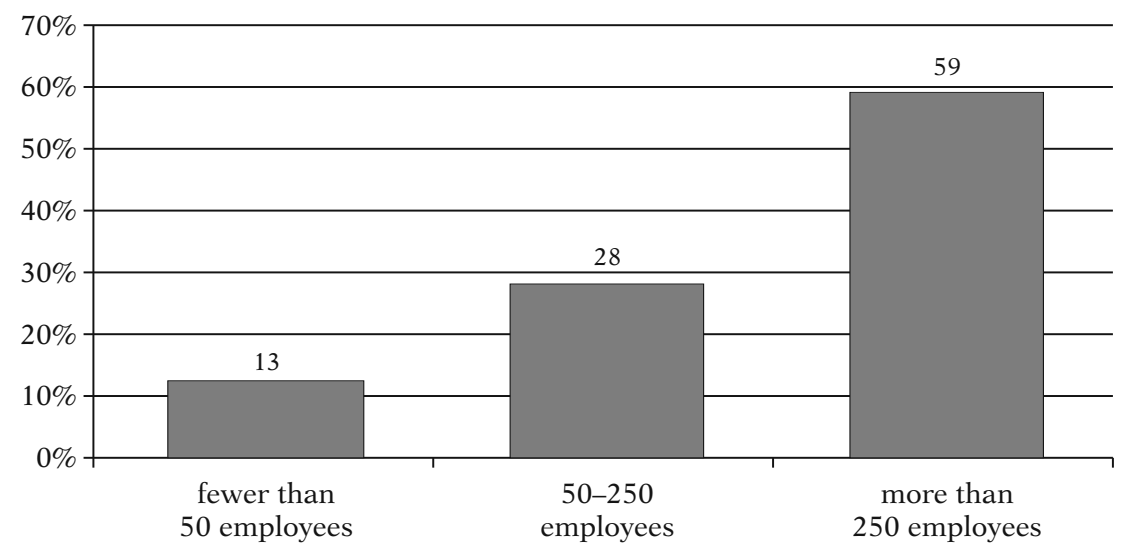

Source: own study.

The main aim of the survey study was to gather the information about the number and category of organizational or individual level interventions. Results show that 30 organizations implemented the stress management intervention at the organizational level (OLI). That amounts to $15 \%$ of the research sample. 40 companies implemented ILI, which is $20 \%$ of the research sample. In 24 companies ( $12 \%$ of the research sample), one can find both types of interventions (OLI and ILI), which tends to be more effective in work-related stress reduction.

In a view of the evidence, that only one-sixth of the companies surveyed had had stress management interventions, the author decided to use mostly raw data rather than percentage points.

Among stress reduction interventions on the organizational level the most common were trainings for supervisors in terms of stress management (21 cases). 15 companies introduced changes in their work organization, such as flexible time practices and altering shifts. Other kinds of OLI included improvements in defining job roles (13 cases), improvements in work conditions and the ergonomics of workstations (10 cases), participatory decision-making at various levels of organization structure (9 cases). One enterprise implemented coaching as a leadership style and other organized program of trainings and 
workshops to develop psychosocial skills of the employees. Those two programs were categorized as "other" in the Figure 3.

Figure 2. The distribution of results different kinds of interventions

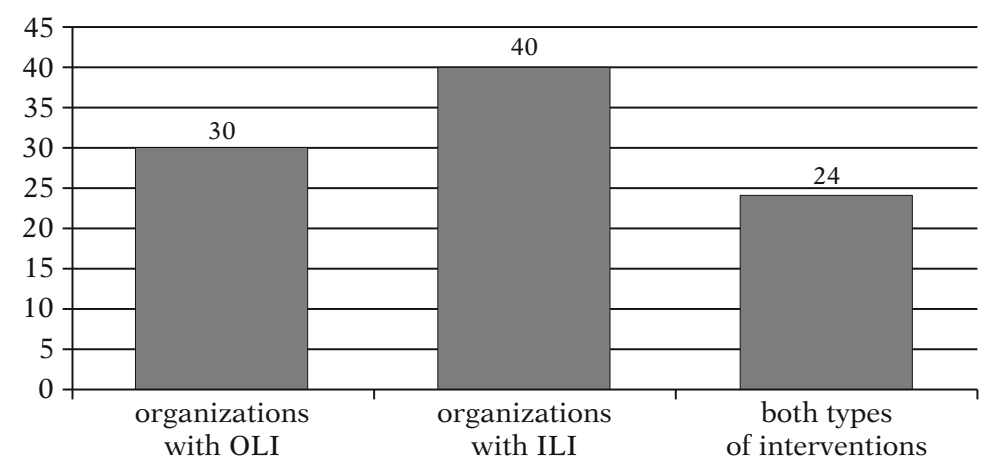

Source: own study.

Figure 3. Categories of OLI implemented in company sample

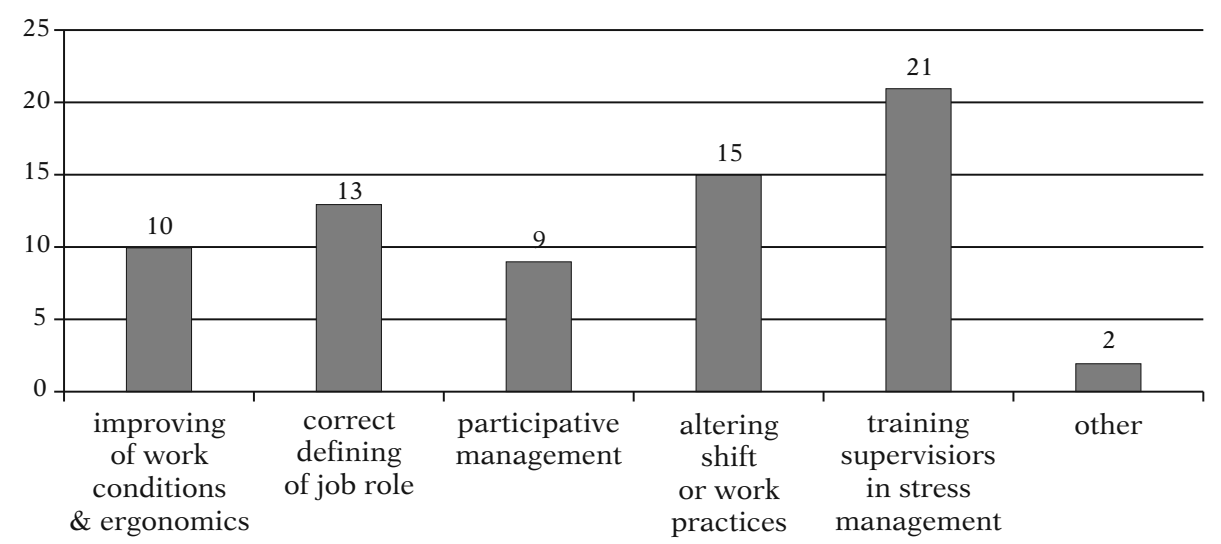

Source: own study.

Individual level interventions are implemented more often than OLI, which was supported by many previous studies. In the studied sample, companies implemented such programs as:

- organizing trainings and workshops in terms of developing stress-coping skills - the most common intervention, occurring in 31 companies,

- supporting employees by arranging the possibility to collaborate with occupational health psychologists (OHPs) or therapists - 24 cases, 
- encouraging employees and financing different kinds of sport activities, both during or after working hours -18 cases,

- promoting healthy lifestyles by organizing seminars, meetings and workshops with experts e.g. physiotherapists, dieticians, occupational physicians, psychologists - 17 cases.

One enterprise offered SPA sessions for the employees and two more sponsored work-life balance workshops. They were assigned to the category "other" in the Figure 4.

Figure 4. Categories of ILI implemented in company sample

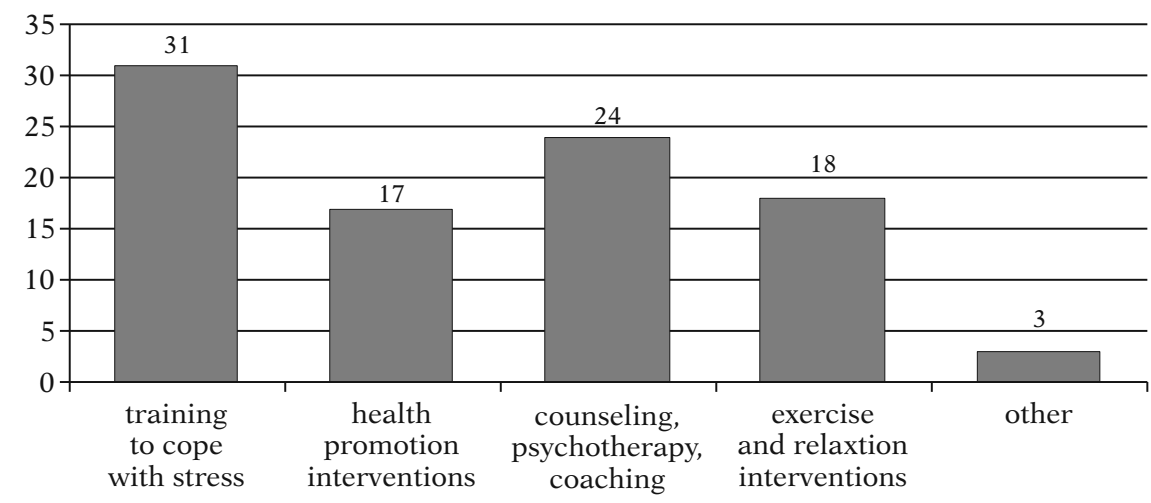

Source: own study.

\section{Methodological problems of the implementations}

On the basis of this study, it is considered that five out of six organizations are not interested in work-related stress reduction. The question is: why? Possible hypotheses are:

- the lack of awareness of psychological and economic effects of stress among the HR managers and the executives/owners of companies,

- the lack of occupational health specialists and advisors who can cooperate with the organizations in the process of implementation of the stress management/reduction interventions,

- the difficulties in using qualitative and methodologically correct methods, e.g. questionnaires, psychological tests, to obtain reliable data in diagnosing the causes of work-related stress, as well as its effects, costs, and coping skills. 
An important element of the present research was to assess the quality and effectiveness of implementations in the surveyed companies. As it was mentioned above, this assessment was done in a non-direct way by analysing the answers from surveys. Four indicators were pointed out as a way to assess the quality of procedure and the effects of implementations. The first was the assessment of the level of stress before and after the intervention. The second was the analysis of the financial costs of absenteeism, decrease of productivity, turnover and staffing process, and work accidents. The third considered psychological costs, such as psychosomatic illness, conflicts, overall fatigue, irritability, sleeping problems and anxiety. The last indicator was related to the precise identification of the sources of stress before the intervention was made.

The results are presented in the Figure 5. They show clearly that the quality of interventions is rather poor. Only 10 companies had assessed the level of stress before they made the intervention. It is about $30 \%$ of the organizations which have done no kind of interventions. The analysis of financial costs had been made in 1 company and the analysis of psychological ones in 4 of them. The sources of stress had been analysed in 16 organizations. This is $7 \%$ of all organizations. There is also a general lack of information about to what extent that kind of analysis was used in the process of planning and organizing the stress management intervention.

Figure 5. Use of quality indicators in the implementation process in company sample

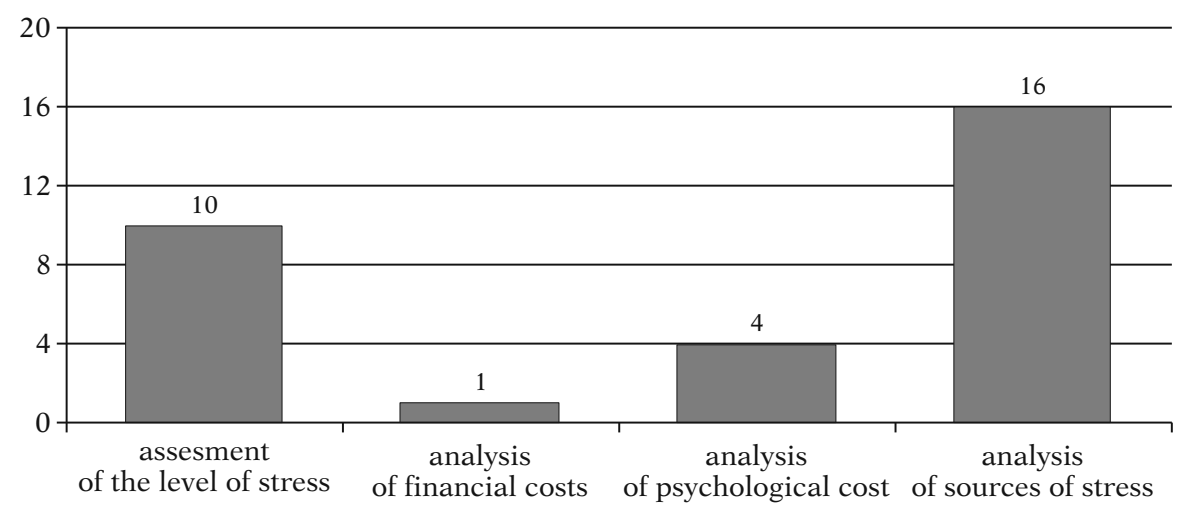

Source: own study.

The data presented above indicate a low level of methodological correctness in the process of stress management interventions in the surveyed companies. This may suggest that the interventions are usually not planned and not well 
organized but rather a kind of last resort for the employees desperately looking for help. According to some HR specialists, interventions may also occur as an effect of receiving additional EU funds which have to be spent on human capital improvements in the organization (personal communication).

\section{Conclusions}

Based on the above survey it can be concluded that few Polish companies are interested in reducing organizational stress. The analysis of the data on implementations of intervention programs, as well as research sources on the costs of stress shows that the few organizations that carry out some activities to reduce stress do not specifically combine them to their personnel strategy. They usually do not close the study of their effectiveness in terms of stress-level reduction or identification of its causes, much less in terms of the actual reduction of the psychological and economic costs of stress.

It is also difficult to speak about the correctness of the methodological stress management interventions in view of the fact that the situation was not usually examined thoroughly either before or after the implementation. Thus, if stress management interventions are introduced on an ad hoc basis and without proper planning or at least setting targets and their verification, one can hardly speak about stress management as a process of planning, organizing and controlling in the Polish context.

The author of the study realizes that these survey data might be erratic due to the subjective assessment of the phenomenon by the respondents, as well as not yet a sufficiently deep analysis of the problem. Nevertheless, the results clearly show the great need to explore this topic in terms of scientific and utilitarian aspects.

In the light of the prior research on the costs and consequences of psychosocial stress it can be concluded that there is a great need to investigate the aspect of occupational stress as a factor affecting the efficiency of the organization. It also seems that there is a need to develop skills and raise awareness of managers (not just personnel) and the entrepreneurs in terms of the effects of occupational stress. 


\section{References}

Cascio W. F., Kalkulacja kosztów zasobów ludzkich, Oficyna Ekonomiczna, Kraków 2001.

Cooper C., Payne R., Stres w pracy, PWN, Warszawa 1987.

Cooper C., Liukkonen P., Cartwright S., Stress Prevention in the Workplace, European Foundation for Improvement of Living and Working Conditions, Dublin 1996.

Cox T., Griffiths A., Rial González E., Research on Work-Related Stress, Report for EU OSHA, Nottingham 2000.

Dalgren A. S., Gard G. E, Soft Values With Hard Impact-a Review of Stress Reducing Interventions on Group and Organizational Level, "Physical Therapy Reviews" 2009, Vol. 14, No. 6.

Dewe P., O’Driscoll M., Stress Management Interventions: What Do Managers Actually Do? "Personel Review" 2002, Vol. 31, No. 1/2.

Gardner B., Rose J., Mason O., Tyler P., Cushway D., Cognitive Therapy and Behavioural Coping in the Management of Work-Related Stress: An Intervention Study, "Work \& Stress" 2005, Vol. 19, No. 2.

Giga S. I., Noblet A., Faragher B., Cooper C., The UK Perspective: A review of Research on Organisational Stress Management Interventions, "Australian Psychologist" 2003, Vol. 38, No. 2.

Graveling R. A., Crawford J. O., Cowie H., Amati C., Vohra S., A Review of Workplace Interventions that Promote Mental Wellbeing in the Workplace, Draft Report, Institute of Occupational Medicine, Edinburgh 2008.

Houtman I., Work-Related Stress, Report for European Foundation for the Improvement of Living and Working Conditions, Dublin 2007.

Janis I., Psychological Stress. Psychoanalytic and Behavioral Studies of Surgical Patients, Wiley\&Sons, New York 1958.

Lazarus R., Psychological Stress and the Coping Process, McGraw-Hill Book Company, USA 1966.

Lazarus R., Folkman S., Stress, Appraisal And Coping, Springer, New York 1984.

Leka S., Jain A., Zwetsloot G., Cox T., Policy-Level Interventions And Work-Related Psychosocial Risk Management In The European Union, "Work \& Stress" 2010, Vol. 24, No. 3.

Milczarek M., Schneider E., Rial González E., OSH In Figures: Stress at Work Facts and Figures, Report for EU OSHA, Luxemburg 2009.

Molek-Winiarska D., Organizacyjne i indywidualne programy zarzadzania stresem, „Współczesne Zarządzanie” 2010, No. 1.

Molek-Winiarska, D., Skutki stresu zawodowego, in: Dysfunkcje i patologie w sferze zarzadzania zasobami ludzkimi, Ed. Z. Janowska, Wydawnictwo Uniwersytetu Łódzkiego, Łódź 2011.

Nielsen K., Randall R., Holten A., Rial González E., Conducting Organizational-Level Occupational Health Interventions: What Works?, "Work \& Stress" 2010, Vol. 24, No. 3. 
Ogińska-Bulik N., Stres zawodowy w zawodach ustug społecznych, Difin, Warszawa 2006.

Reykowski J., Funkcjonowanie osobowości w warunkach stresu psychologicznego, PWN, Warszawa 1966.

Richardson K. M., Rothstein R. H., Effect of Occupational Stress Management Intervention Programs. A Meta-Analysis, "Journal of Occupational Health Psychology" 2008, Vol. 13, No. 1.

Schabracq M. J., Winnubst J. A., Cooper C. L., Work \& Health Psychology, John Wiley\&Sons, West Sussex 2003.

Selye H., Stres okietznany, PIW, Warszawa 1977.

Terelak J., Stres psychologiczny, Oficyna Wydawnicza Branta, Bydgoszcz 1995.

Van der Klink J. J. L., Blonk R. W. B, Schene A. H., van Dijk F. J. H., The Benefits of Interventions for Work-Related Stress, "American Journal of Public Health" 2001, Vol. 91, No. 2.

\section{Резюме}

\section{Интервенции в управлении стрессом на польских предприятиях - результаты исследований}

Все чаще проводимые исследования, посвященные изучению стресса на работе и программ его снижения, позволяют формулировать некоторые выводы и модели. Тем не менее способ изучения этих явлений по-прежнему несовершенен. Итак, существует потребность в сравнительных исследованиях разных программ в организациях, а также в создании инструкции по их внедрению. В настоящей статье описаны исследования, которые должны дать ответы на вопросы: Знают ли польские предприниматели идею программ снижения стресса? Были ли имплементации проведены с учетом изучения источников, цены и последствий стресса? Какова эффективность этих действий? Результаты показывают, что 45\% предпринимателей знает идею программ снижения профессионального стресса, а около 17\% внедряет их. Наиболее часто применяемыми интервенциями являются организуемые для менеджеров учебные курсы по управлению стрессом, а также предназначенные для работников занятия по обучению техникам снижения стресса. Однако анализ этих внедрений свидетельствует о наличии ряда недостатков в процессе имплементации.

Ключевые слова: профессиональный стресс, программа снижения стресса, продвижение здоровья в рабочей среде, цена, релаксация. 


\section{Dorota Molek-Winiarska, Ph.D.}

She works in the Human Resources Management Department in Wroclaw University of Economics. She is a psychologist and she did her Ph.D. in Management Science. She is also a human resources consultant and a trainer and works with managers. They cooperate in terms of effective communication and motivation systems, employees recruitment and development. The field of her study is connected with industrial/organizational psychology and she specializes in occupational stress and stress management interventions. She is also a member of the Polish Psychological Association and the Polish Association of Organizational Psychology. 